\title{
Herpetofauna of Núcleo Experimental de Iguaba Grande, Rio de Janeiro state, Brazil
}

\author{
Martins, AR. ${ }^{a^{*}}$, Bruno, SF. ${ }^{b}$ and Navegantes, AQ. ${ }^{c}$ \\ aSetor de Herpetologia, Departamento de Vertebrados, Museu Nacional, Universidade Federal do Rio de Janeiro - UFRJ, \\ Quinta da Boa Vista, s/n, CEP 20940-040, Rio de Janeiro, RJ, Brazil

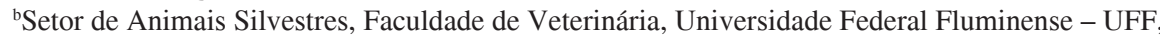 \\ Rua Vital Brazil Filho, 64, Santa Rosa, CEP 24230-340, Niterói, RJ, Brazil \\ 'Programa de Pós-graduação em Ecologia, Departamento de Ecologia, Instituto de Biologia, \\ Universidade Federal do Rio de Janeiro - UFRJ, Av. Carlos Chagas Filho, 373, Ilha do Fundão, CEP 21941-902 \\ Cidade Universitária, Rio de Janeiro, RJ, Brazil \\ *e-mail: angelemartins@gmail.com
}

Received March 31, 2011 - Accepted September 8, 2011 - Distributed August 31, 2012

(With 4 figures)

\begin{abstract}
The Atlantic Rain forest, which is considered the second largest pluvial forest in the American continent, has had an estimated $93 \%$ of its original area destroyed. Although studies concerning the herpetofaunal diversity in this biome have been intensified in the past years, its diversity is still underestimated. The Nucleo Experimental de Iguaba Grande (NEIG) is included in an Environmental Protection Area (APA de Sapeatiba) in the Iguaba Grande municipality, Rio de Janeiro state, Brazil $\left(22^{\circ} 51^{\prime} \mathrm{S}\right.$ and $\left.42^{\circ} 10^{\prime} \mathrm{W}\right)$. The goal of this study was to conduct an inventory of the reptile and amphibian species that occur in this area between July 2008 and December 2009. We recorded 19 species of amphibians (18 anurans and one caecilian) and 15 species of reptiles (three lizards, 11 snakes and one amphisbaenian). Leptodactylus latrans and L. mystacinus had the highest capture rates among amphibians captured, and among reptiles, Ameiva ameiva, Hemidactylus mabouia and Mabuya agilis had the highest capture rates. Rarefaction curves for both amphibians and reptiles did not reach the asymptote, indicating that the species richness in the NEIG is still underestimated.
\end{abstract}

Keywords: Atlantic Rain-forest, amphibians, reptiles, inventory, restinga.

\section{Herpetofauna do Núcleo Experimental de Iguaba Grande-Rio de Janeiro, Brasil}

\section{Resumo}

A Floresta Atlântica é considerada a segunda maior floresta pluvial tropical do continente americano, embora seja estimado que mais de $93 \%$ de sua cobertura original tenha sido destruída. Estudos sobre a diversidade da herpetofauna da Mata Atlântica têm-se intensificado nos últimos anos, embora o conhecimento sobre a diversidade herpetofaunística desse bioma ainda seja considerado subestimado. O Núcleo Experimental de Iguaba Grande (22 $51^{\prime}$ S and $\left.42^{\circ} 10^{\prime} \mathrm{W}\right)$ está inserido na Área de Proteção Ambiental de Sapeatiba (APA de Sapeatiba), no município de Iguaba Grande, Estado do Rio de Janeiro, Brasil. Objetivou-se, nesta pesquisa, realizar um levantamento das espécies de anfíbios e répteis de ocorrência nesta área, no período de julho de 2008 a dezembro de 2009. Foram registradas 19 espécies de anfíbios (18 anuros e uma cecília) e 15 espécies de répteis (três lagartos, 11 serpentes e um anfisbenídeo). As espécies Leptodactylus latrans e L. mystacinus representaram as maiores taxas de captura dentre as espécies de anfíbios capturados, enquanto que, para répteis, as maiores taxas de captura foram obtidas para Ameiva ameiva, Hemidactylus mabouia e Mabuya agilis. A curva de rarefação tanto para anfíbios quanto para répteis não atingiu a assíntota, indicando que a riqueza da área ainda está subestimada.

Palavras-chave: Mata Atlântica, anfíbios, répteis, inventário, restinga. 


\section{Introduction}

The Neotropical herpetofauna, particularly in Brazil, is considered one of the most diverse on the planet (Vitt, 1987; Duellman, 1988, 1989, 1990; Rodrigues, 2005). Although Brazilian herpetofaunal biodiversity is impressive, its composition is still largely unknown (Rodrigues, 2005; Silvano and Segalla, 2005).

The Atlantic Rainforest originally covered a total area equivalent to approximately $13 \%$ of Brazil, and it is estimated that more than $93 \%$ of this original area has been destroyed (IPEMA, 2005). Despite the enormous amount of anthropic disturbances, this biome still harbours a significant portion of the biological diversity in Brazil (IPEMA, 2005; MYERS et al., 2000).

In the state of Rio de Janeiro, in particular, the Atlantic Rainforest remnants currently represent around $20 \%$ of its original area (Fundação SOS Mata Atlântica; INPE, 2001). Although conservation initiatives have grown in number and scale over the past two decades, they are still insufficient to properly ensure the conservation of biodiversity in the Atlantic forest (Tabarelli et al., 2004).

Studies of amphibian and reptile diversity in Atlantic Rainforest areas have grown considerably over the past five years (e.g., Dixo and Verdade, 2006; Juncá, 2006; Moraes et al., 2007; Colombo et al., 2008; Carvalho-e-Silva et al., 2008; Lucas and Fortes, 2008; Santana et al., 2008; Serafim et al., 2008; Bertoluci et al., 2009; Narvaes et al., 2009; Marques et al., 2009; Araujo et al., 2010; Wachlevski and Rocha, 2010; Costa et al., 2010; Sousa et al., 2010; Vilela et al., 2011). For example, the number of studies concerning the composition of local amphibian and reptile fauna have also increased in this period in the state of Rio de Janeiro (e.g., Rocha and Van Sluys, 2006; Carvalho et al., 2007; Carvalho-e-Silva et al., 2000; Rocha et al., 2008; Silva et al., 2008; Pontes et al., 2009; Salles and Silva-Soares, 2010; Salles et al., 2010; Almeida-Gomes et al., 2008, 2010). Nevertheless, more long-term studies are still necessary in order to provide enough knowledge about the herpetofaunal diversity in this state.

In this work, we present results of a herpetofaunal survey, which was conducted on a predominantly restinga habitat within the Atlantic Rainforest biome in the state of Rio de Janeiro, in order to provide data about the local species composition.

\section{Material and Methods}

\subsection{Study site}

This study was conducted in The Núcleo Experimental de Iguaba Grande (NEIG/UFF - 22 ${ }^{\circ} 51^{\prime} \mathrm{S}$ and $42^{\circ} 10^{\prime} \mathrm{W}$ ), located within the municipality of Iguaba Grande, in the state of Rio de Janeiro, Brazil (Figure 1). This area is located within the Environmental Protection Area (APA) of Sapeatiba, with an area of 169.4 ha, of which 135.52 ha are composed of restinga and dry forest, and 33.88 ha by disturbed areas. The NEIG consists of a mosaic of habitats marked by the presence of some patches of typical restinga vegetation, tropical dry forest and disturbed areas (Vecchi and Alves, 2008), and is located approximately $11 \mathrm{~km}$ from the Atlantic Ocean, bounded northward by the RJ-106 highway and southward by the Araruama lagoon (CPRM, 2000). Moreover, the NEIG represents the most conserved remnant area in the northern portion of Araruama Lagoon Basin (Silveira-Primo and Bizerril, 2000). In the study area, the restinga habitats are restricted to the southern edge, which faces the Araruama lagoon and consists of typical restinga vegetation. The dry forest habitats are the predominant vegetation types in the area, extending from the northern edge of the area, through the central portions until facing the restinga areas in the southern edge. It consists of a shrubby area with evenly-spaced trees that are adapted for an arid climate and high intensity winds (Silveira-Primo and Bizerril, 2000). The disturbed areas consist of those that have been occupied by buildings or those that have been cleared for use as pasture (S.F. Bruno pers. comm.; Figure 1). Moreover, the boundaries of these different vegetation types are difficult to discern probably because this area has not been the object of specific studies of its vegetation (Lamego, 1974; Vecchi and Alves, 2008).

\subsection{Data collection}

Fieldwork was conducted between two and four consecutive days bimonthly from July 2008 to December 2009. Searches occurred during the day and at night, and totalled 36 field trips, 91 days and 54 nights of fieldwork. During data collection, the number of collectors ranged from one to four per day. The herpetofauna was sampled through the use of pitfall traps with drift fences (Cechin and Martins, 2000); active searches (not time-constrained) (Heyer, 1994) and occasional encounters. Pitfall systems were distributed along four lines. Each line was set in one vegetation type - Line 1: dry forest; Line 2: restinga; Line 3: transition between restinga and dry forest; and Line 4: disturbed area (Figure 2). Each line contained eight 60-litre buckets with small holes and a sheet of styrofoam at the bottom. The buckets were buried in the ground, set five metres apart from each other, and linked by plastic fences $60 \mathrm{~cm}$ high. The traps were opened during all days of the study (from July 2008 to December 2009), and checked every day, or every two days, totalling 405 hours of sampling effort per bucket.

The active searching method consisted in walking slowly along the pre-existing roads and trails of the NEIG and searching every type of microhabitat (e.g. leaf litter, twigs, trunks, under stones, in stumps, holes in the ground and in hollow trees). This method was performed during the morning, afternoon and evening, totalling 900 hours off effort. Occasional encounters with live animals and carcasses found in the NEIG were also considered for the diversity data results.

Representative specimens of each species were fixed in $10 \%$ formalin and housed as vouchers at the Museu Nacional, Universidade Federal do Rio de Janeiro (MNRJ). Other captured specimens not intended as representative 


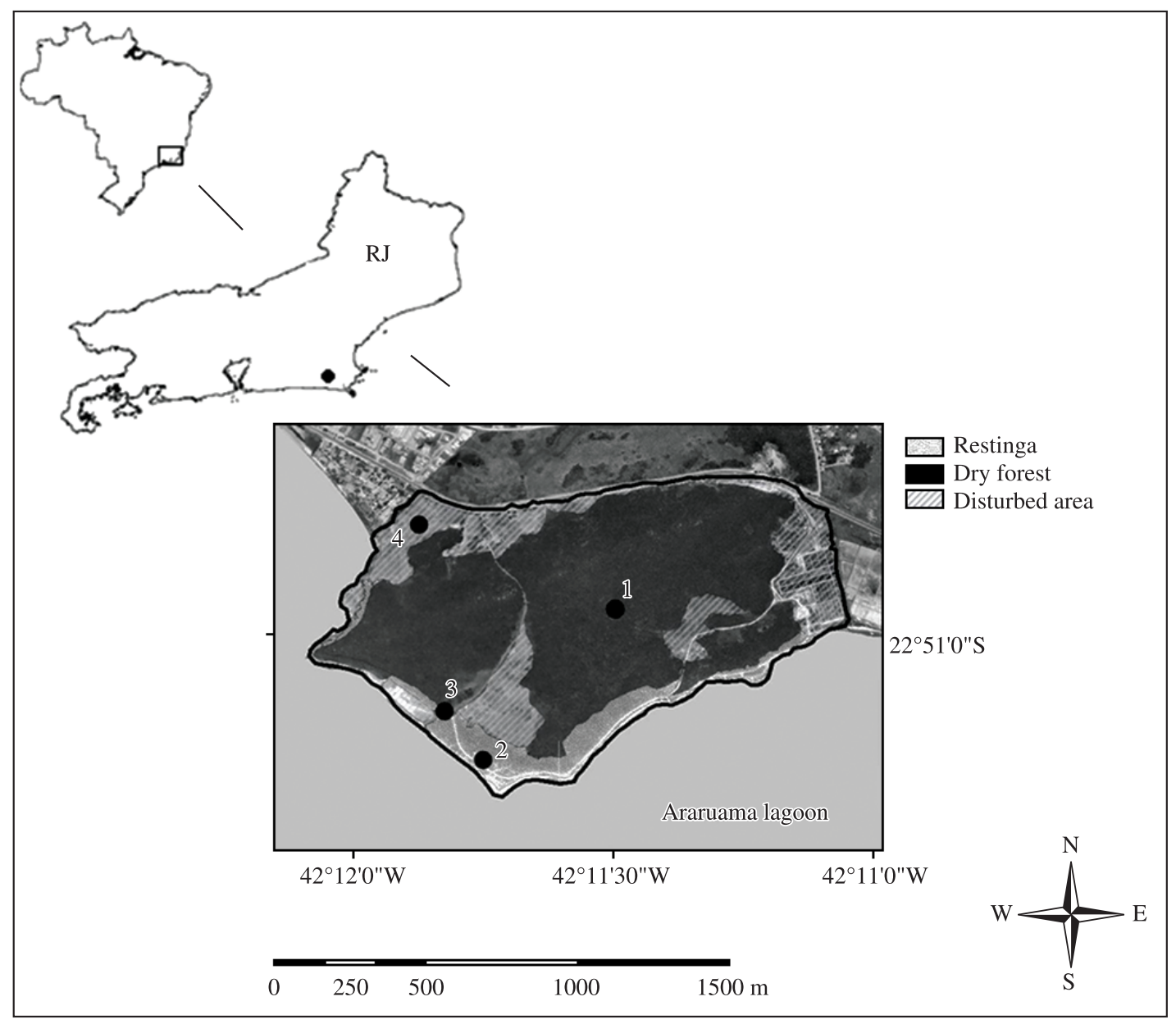

Figure 1. Location of the study area of Nucleo Experimental de Iguaba Grande, Iguaba Grande municipality, Rio de Janeiro state, southeastern Brazil, and characterization of the three vegetation types in the NEIG: restinga, dry forest and disturbed area. Dots indicate lines of pitfall traps used in the study, each one established in one vegetation type. Line 1: Dry forest, Line 2: Restinga, Line 3: Transition between dry forest and restinga, Line 4: Disturbed area.
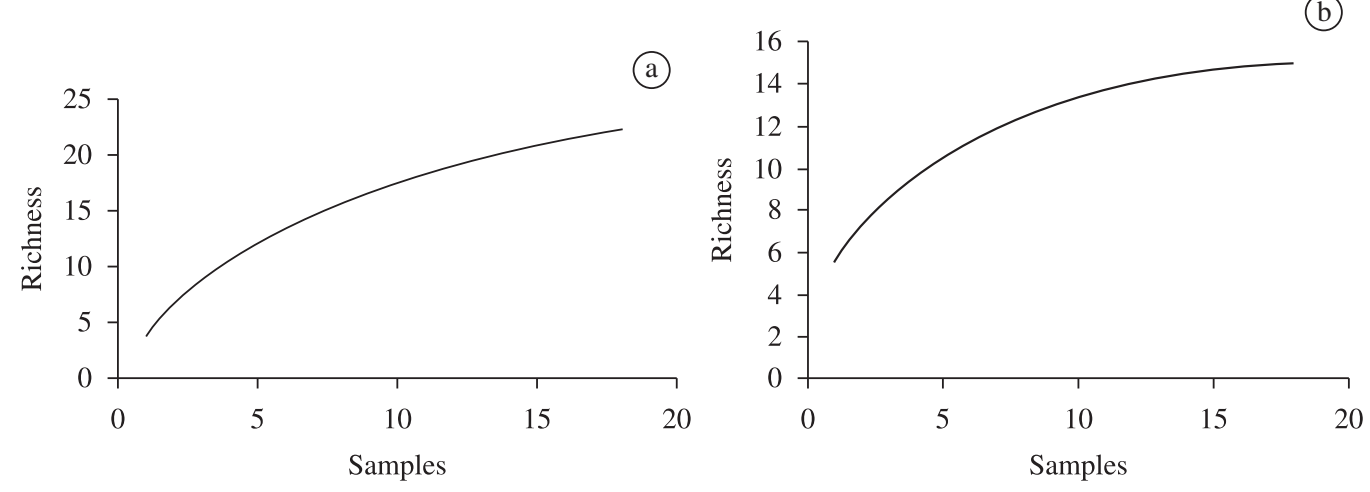

Figure 2. Rarefaction curve of the sampled species of amphibians (a) and reptiles (b) in Núcleo Experimental de Iguaba Grande, Rio de Janeiro state, between July 2008 and December 2009. Samples indicate the period of study (July 2008 to December 2009). 
specimens were released near their original capture location. The collection of specimens was permitted by IBAMA (license numbers: 16584-1 and 16584-2).

\subsection{Data analysis}

We used the Kruskall-Wallis H-test to check the significance of the difference between capture rates in all four pitfall lines. Tests were performed using the Statistica 7 program, and were based on the period in which all lines had the same bucket/hour sampling (i.e. February 2009 to August 2008; 1040bucket-hours).

In order to check sample efficiency, we used the program EstimateS (version 6.0b1) to obtain a rarefaction curve of the sampled amphibians and reptiles. The curve was obtained through 1000 randomizations and using a Jackknife estimator.

\section{Results}

We recorded 34 species in the NEIG, including 19 amphibians (18 anurans and 1 caecilian) and 15 reptiles (three lizards, 12 snakes and 1 amphisbaenian). Amphibians were represented by five families: Hylidae (13 spp.), Bufonidae (two spp.), Leptodactylidae (two spp.), Hemiphractidae (one sp.) and Caeciliidae (one sp.) (Table 1). Reptiles were represented by the families: Scincidae (one sp.), Teiidae (one sp.), Gekkonidae (one sp.), Dipsadidae (four spp.), Colubridae (four spp.), Typhlopidae (one sp.), Elapidae (one sp.), Boidae (one sp.) and Amphisbaenidae (one sp.) (Table 1). The active searching method registered $82 \%$ of the total species $(n=28)$, while pitfall traps registered $37 \%(\mathrm{n}=13)$. Occasional encounters generated records for 14 species, which were represented by six live animals (17\%) and eight carcasses (22\%).

Rarefaction curves of both amphibians and reptiles did not reach the asymptote (Figure 2).

Among the amphibian species recorded at the NEIG, Leptodactylus latrans and L. mystacinus had the highest capture rates, which together represented $70 \%$ of individuals captured (Figure 3a). Furthermore, these two anuran species were found in all vegetation types, including temporary water bodies in both restinga and dry forest and in disturbed areas (Figure 4a). The species Phyllomedusa rohdei, Scinax fuscovarius, Scinax similis, Scinax aff. x-signatus, Denderopsophus elegans, Dendropsophus meridianus, Scinax littoreus and Sphaenorhynchus planicola had more than 10 captures each, whereas the other species not mentioned above had less than 10 captures each (Figure 3a).

Among reptile species recorded, A. ameiva, M. agilis and $H$. mabouia (all lizard species recorded in this study) had the higher capture rates, with more than 65 captures each (Figure 3b). Together, these three lizard species represented $80 \%$ of the total of individuals recorded. The snake species Tantilla sp. and O. aeneus had more than 10 captures each in this study, whereas other snake species had lower capture rates, (i.e., <6 captures each; Figure 4b).
Differences between capture rates in each pitfall line was not significant for both amphibian $(\mathrm{H}=3.8, \mathrm{df}=3$, $\mathrm{p}=0,29)$ and reptile species $(\mathrm{H}=4.0, \mathrm{df}=3, \mathrm{p}=0,26)$.

\section{Discussion}

\subsection{Amphibian community}

The amphibian species diversity in the NEIG resembles those reported in other studies conducted in restinga habitats along the Brazilian coast (e.g., Britto-Pereira et al., 1988; Carvalho-e-Silva et al., 2000; Rocha et al., 2008; Silva et al., 2008), with the family Hylidae also being the most representative family among recorded amphibians.

Most of the amphibian species registered for NEIG were recorded from restinga habitats (Figure 4), in which the animals were commonly associated with bromeliads or near temporary water bodies, with the highest capture rates occurring during the rainy seasons.

Except for Scinax littoreus, Trachycephalus nigromaculatus, Phyllomedusa rohdei, P. burmeisteri and Dendropsohus elegans, the other species were associated with permanent water bodies in restinga habitats in the NEIG. Scinax littoreus was recorded only inside bromeliads in bushy restinga habitats. Trachycepahlus nigromaculatus was found inside bromeliads in dry forest and in shrubby and bushy areas of restinga habitats. Dendropsophus elegans and $P$. rohdei were both found in the dry forest after rainy periods or associated with water bodies near the bushy areas and bromeliads. Phyllomedusa burmeisteri had a single record for dry forest vegetation near a water body distant from the coast.

Among amphibian species registered in the present study, with the exceptions of Sphaenorhyncus planicola, Scinax littoreus and Rhinella pygmaea, all other species recorded have a wide distribution in the Atlantic Forest (Haddad et al., 2008). Leptodactylus latrans and Trachycephalus nigromaculatus can also occur in the Cerrado and the Amazon (Haddad et al., 2008; Dias et al., 2010). Scinax fuscovarius and Leptodactylus mystacinus are also known to occur in the Cerrado and Caatinga biomes (Freitas and Silva, 2007). Sphaenorhyncus planicola has a restricted distribution in the Atlantic forest, only occurring in the states of Rio de Janeiro and Espirito Santo, while Scinax littoreus and Rhinella pygmaea are endemic to restinga environments (Carvalho-e-Silva et al., 2000; Rocha et al., 2008).

Although S. fuscovarius was found to be associated with the restinga habitats in the present study, this species was not listed by Rocha et al. (2008) for some restingas of Rio de Janeiro, Espirito Santo and Bahia states, nor by Carvalho-e-Silva et al. (2000) for restingas along the Brazilian coast. Trachycepahlus nigromaculatus, Dendropsophus elegans and $P$. rohdei had been listed for restinga habitats in southeastern Brazil by Carvalho-e-Silva et al. (2000), but were not present in the listings of Rocha et al. (2008) for restingas of Rio de Janeiro, Espirito Santo and Bahia states. Although the single record of Phyllomedusa burmeisteri occurred outside the typical restinga areas, this species 
Table 1. List of amphibian and reptile species registered on the NEIG, in Iguaba Grande, Rio de Janeiro state, Brazil, with sampling methods and sampled habitats.

\begin{tabular}{|c|c|c|}
\hline Taxonomic categories & Sampling method & Habitat type \\
\hline \multicolumn{3}{|l|}{ Lissamphibia Anura } \\
\hline \multicolumn{3}{|l|}{ Family Bufonidae } \\
\hline Rhinella ornata (Spix, 1824) & AS, PT & $\operatorname{Re}$ \\
\hline Rhinella pygmaea (Myers and Carvalho, 1952) & $\mathrm{CO}$ & DA \\
\hline \multicolumn{3}{|l|}{ Family Hemiphractidae } \\
\hline \multicolumn{3}{|l|}{ Flectonotus sp. Miranda-Ribeiro, 1926 AS Re } \\
\hline \multicolumn{3}{|l|}{ Family Hylidae } \\
\hline Dendropsophus anceps (A. Lutz, 1929) & AS, OE & $\operatorname{Re}$ \\
\hline Dendropsophus decipiens (A. Lutz, 1925) & AS & $\operatorname{Re}$ \\
\hline Dendropsophus elegans (Wied-Neuwied, 1824) & AS, OE & $\mathrm{Re}, \mathrm{DF}$ \\
\hline Dendropsophus meridianus (B. Lutz, 1954) & AS & $\operatorname{Re}$ \\
\hline Hypsiboas albomarginatus (Spix, 1824) & AS, OE & $\mathrm{Re}$ \\
\hline Phyllomedusa burmeisteri Boulenger, 1882 & AS & $\mathrm{DF}$ \\
\hline Phyllomedua rohdei Mertens, 1926 & $\mathrm{AS}, \mathrm{OE}$ & $\mathrm{Re}, \mathrm{DF}$ \\
\hline Scinax fuscovarius (A. Lutz, 1925) & AS & $\operatorname{Re}$ \\
\hline Scinax littoreus (Peixoto, 1988) & AS & $\mathrm{Re}$ \\
\hline Scinax similis (Cochran, 1952) & AS & $\operatorname{Re}$ \\
\hline Scinax aff. $x$-signatus (Spix, 1824) & AS & $\operatorname{Re}$ \\
\hline Sphaenorhyncus planicola (A. Lutz and B. Lutz, 1938) & AS & $\operatorname{Re}$ \\
\hline Trachycephalus nigromaculatus Tschudi, 1838 & $\mathrm{AS}, \mathrm{OE}$ & $\mathrm{Re}, \mathrm{DF}$ \\
\hline \multicolumn{3}{|l|}{ Family Leptodactylidae } \\
\hline Leptodactylus latrans (Steffen, 1815) & AS, PT, OE & $\mathrm{Re}, \mathrm{DF}, \mathrm{DA}$ \\
\hline Leptodactylus mystacinus (Burmeister, 1861) & AS, PT & $\mathrm{Re}, \mathrm{DF}, \mathrm{DA}$ \\
\hline \multicolumn{3}{|l|}{ Gymnophiona } \\
\hline \multicolumn{3}{|l|}{ Family Caeciliidae } \\
\hline Chthonerpeton sp. Peters, 1880 & $\mathrm{CO}$ & - \\
\hline \multicolumn{3}{|l|}{ Reptilia } \\
\hline \multicolumn{3}{|l|}{ Squamata } \\
\hline \multicolumn{3}{|l|}{ Family Amphisbaenidae } \\
\hline Amphisbaena scutigera (Hemprich, 1829) & $\mathrm{Ca}$ & DA \\
\hline \multicolumn{3}{|l|}{ Family Boidae } \\
\hline Boa constrictor constrictor Linnaeus, 1758 & $\mathrm{AS}, \mathrm{Ca}, \mathrm{CO}, \mathrm{OE}$ & $\mathrm{DF}, \mathrm{Re}, \mathrm{DA}$ \\
\hline \multicolumn{3}{|l|}{ Family Colubridae } \\
\hline Chironius bicarinatus (Wied, 1820) & $\mathrm{PT}, \mathrm{AS}, \mathrm{OE}$ & $\mathrm{DF}, \mathrm{Re}$ \\
\hline Tantilla sp. Baird and Girard, 1853 & PT & $\mathrm{DF}, \mathrm{Re}$ \\
\hline Oxybelis aeneus (Wagler, 1824) & PT, AS, Ca, OE & $\mathrm{DF}, \mathrm{Re}, \mathrm{DA}$ \\
\hline Leptophis ahaetulla (Linnaeus, 1758) & $\mathrm{AS}, \mathrm{OE}$ & DF \\
\hline \multicolumn{3}{|l|}{ Family Dipsadidae } \\
\hline Philodryas olfersii (Lichtenstein, 1823) & $\mathrm{AS}, \mathrm{OE}$ & DF \\
\hline Philodryas patagoniensis (Girard, 1858) & $\mathrm{PT}, \mathrm{AS}, \mathrm{CO}, \mathrm{Ca}, \mathrm{OE}$ & $\mathrm{DF}, \mathrm{Re}, \mathrm{DA}$ \\
\hline Liophis miliaris (Linnaeus, 1758) & PT, AS, Ca & $\operatorname{Re}$ \\
\hline \multicolumn{3}{|l|}{ Family Elapidae } \\
\hline Micrurus ibiboboca (Merrem, 1820) & AS & $\operatorname{Re}$ \\
\hline \multicolumn{3}{|l|}{ Family Gekkonidae } \\
\hline Hemidactylus mabouia (Moreau de Jonnès, 1818) & PT, AS, OE & $\mathrm{DF}, \mathrm{Re}, \mathrm{DA}$ \\
\hline \multicolumn{3}{|l|}{ Family Scincidae } \\
\hline Mabuya agilis (Raddi, 1823) & $\mathrm{PT}, \mathrm{AS}, \mathrm{Ca}, \mathrm{OE}$ & $\mathrm{Re}, \mathrm{DA}$ \\
\hline \multicolumn{3}{|l|}{ Family Teiidae } \\
\hline Ameiva ameiva (Linnaeus, 1758) & PT, AS, CO, Ca & $\mathrm{DF}, \mathrm{Re}, \mathrm{DA}$ \\
\hline \multicolumn{3}{|l|}{ Family Typhlopidae } \\
\hline Typhlops brongersmianus Vanzolini, 1976 & PT & $\mathrm{DF}, \mathrm{Re}, \mathrm{DA}$ \\
\hline
\end{tabular}

$\mathrm{PT}=$ pitfall trap; $\mathrm{AS}=$ active search $\mathrm{OE}=$ occasional encounters $\mathrm{CA}=$ carcass $\mathrm{CO}=$ collected by others; $\mathrm{Re}=$ restinga; $\mathrm{DF}=$ dry forest $\mathrm{DA}=$ disturbed area. 
had been listed by Carvalho-e-Silva et al. (2000) to occur in restinga habitats in southeastern Brazil.

Leptodactylus latrans and Leptodacytlus mystacinus had the highest capture rates, besides being captured in all vegetation types in the study area. These species have wide distribution in Brazil, and are favoured by their adaptability and resistance to disturbed areas (Izecksohn and Carvalho-e-Silva, 2001; Haddad et al., 2008).

None of the species recorded in the area was included on the national list of threatened amphibian species (IBAMA, 2003). The lone record for the caeciliid Chtonerpeton sp., from our study may represent a species that has not yet been formally described (see Rocha et al., 2004b). Flectonotus sp. could not be identified because the single collected specimen was an immature, making it difficult to identify the specimen.

\subsection{Reptile community}

Similar to the amphibian diversity, reptile diversity in the NEIG resembles the findings of other studies conducted in restinga habitats along the Brazilian coast (e.g. Rocha et al. 2004a; Dias and Rocha, 2005; Carvalho et al.,
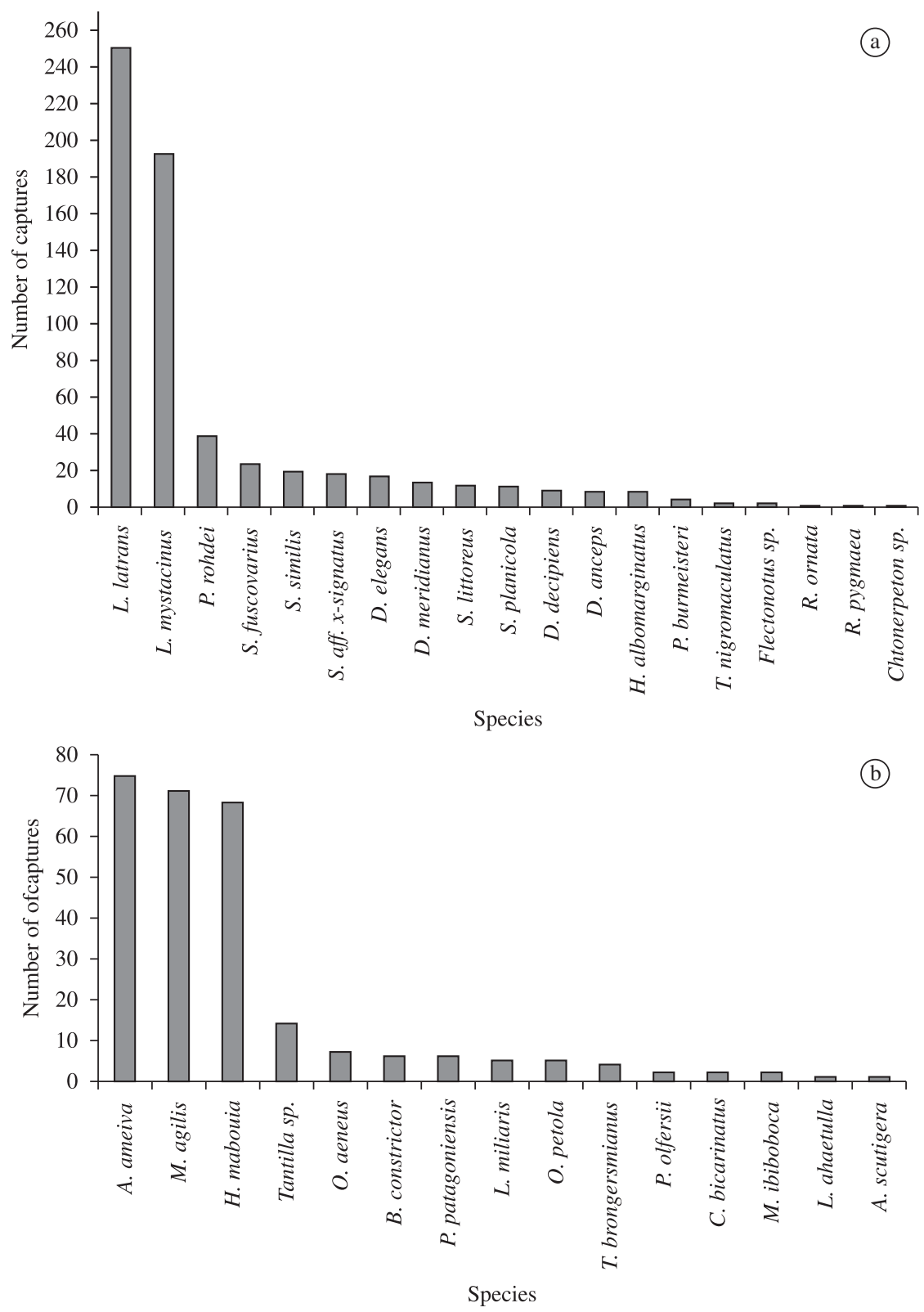

Figure 3. Number of captures of amphibian (a) and reptile (b) species in Núcleo Experimental de Iguaba Grande, Rio de Janeiro state. 
2007). None of the species recorded in the area is included on the national list of threatened reptile species (IBAMA, 2003).

Ameiva ameiva, Boa constrictor, Philodryas patagoniensis, Hemidactylus mabouia and Oxybelis aeneus were widely distributed in the area, covering all areas of the study site. Mabuya agilis was restricted to the border of dry forest areas and to shrubby restinga areas. The distribution of this species in the study area may be heavily influenced by the higher concentration of grasses in the recorded habitats, limiting its distribution to these habitats (Rocha and Bergallo, 1997). Leptophis ahaetulla, Philodryas. olfersii and Oxyrhopus petola were restricted to dry forest areas, while Micrurus ibiboboca and Chironius bicarinatus were recorded in both dry forest and bushy areas of restinga habitats after rainy days. Liophis miliaris has only been recorded near permanent water bodies, which can be explained by its semi-aquatic habit (Pontes and Rocha, 2008). Our record of Typhlops brongersmianus for Iguaba Grande expands to the south the species previous known range the state (Martins et al., 2010). The distribution of Amphisbaena scutigera within NEIG was not determined because only a single specimen was found dead on the highway that borders the study area. All records for the Tantilla sp. - which could not be identified at species level because it might represent a new species - were all restricted to better preserved areas (all areas of restinga and dry forest).

Except for Micrurus ibiboboca, which may also be found in the Caatinga region of northeast Brazil (Vanzolini et al., 1980; Campbell and Lamar, 2004), and Tantilla sp., other snake records included species with wide distribution in most Brazilian biomes (Pontes and Rocha, 2008), as well as in other countries. Boa constrictor can be found not only
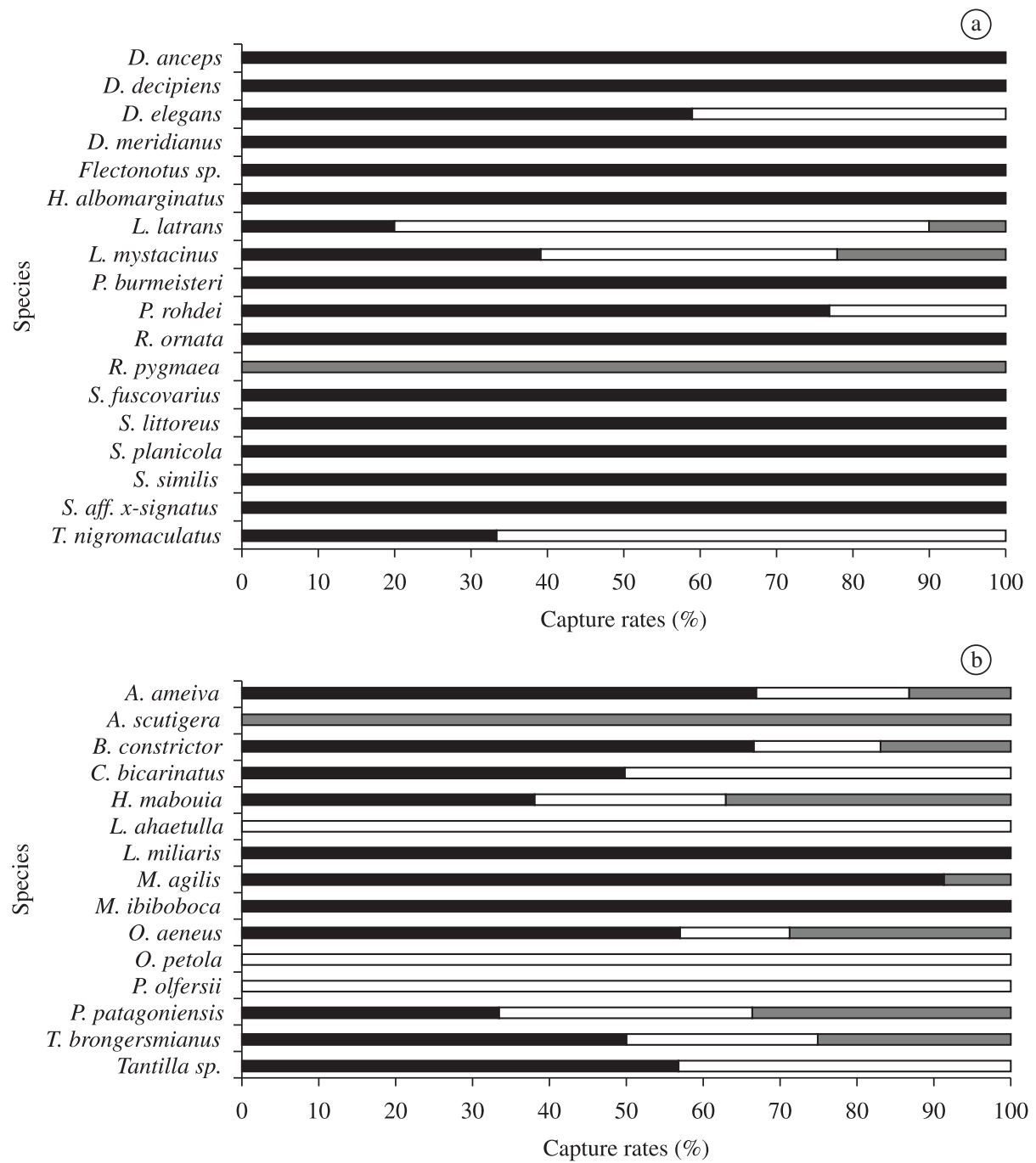

Figure 4. Capture rates (\%) per species of amphibians (a) and reptiles (b) in pitfall traps and during active search in three habitats of Núcleo Experimental de Iguaba Grande, Rio de Janeiro state. White bars = dry forest; gray bars = disturbed area; Black bars = restinga. 
in areas of Atlantic Rainforest and Amazon forests but also in open areas such as Cerrado and Caatinga (Pontes and Rocha, 2008). O. aeneus, P. olfersii and L. ahaetulla may be found in areas of the Atlantic Rainforest and also in the Amazon (Pontes and Rocha, 2008).

Hemidactylus mabouia and Ameiva ameiva have wide distributions in Brazil, occurring also in the Amazonia, Cerrado and Caatinga biomes (Freitas and Silva, 2007), while Mabuya agilis occurs continuously along much of the southeastern Brazilian coast from Rio de Janeiro to southern Bahia (Rocha and Bergallo, 1997; Rocha, 2000). These species had the highest capture rates registered in the NEIG the most abundant lizards in Brazilian restingas (Rocha and Bergallo, 1997).

Tropidurus torquatus and Ameiva ameiva were the only species that occurred in all restingas studied along southeastern and northeastern Brazil . The species T. torquatus was the most abundant species in all restingas, which seems to result from the considerable generalization of several aspects of the species ecology, diet, activity and reproductive aspects (Araújo, 1984; Bergallo and Rocha, 1993; Rocha and Bergallo, 1994; Teixeira-Filho et al., 2003; Gandolfi and Rocha, 1998). These generalized characteristics (in relation to other species) probably allow T. torquatus to maintain a high population size in restingas (Rocha and Bergallo, 1997). However, our results show that $T$. torquatus was not registered in the study area, and it was not even seen in the surrounding areas. These data lead us to question the absence of the species in the study area; nevertheless, more focused studies are still necessary in order to answer such question. Ecological factors, along with the age and the state of restinga formations as well as the processes of colonization by species of reptiles are responsible for a considerable part of the composition, structure and organization of these communities in restinga habitats (Rocha, 2000). However, with the current limitations of knowledge about the communities of reptiles and the processes occurring in the past and present in such habitats, studies are still needed to achieve a greater understanding of historical factors and ecological determinants of the variation between areas in reptiles communities (Rocha and Bergallo, 1997).

Although the sampling period exceeded one year, the rarefaction curves for both amphibians and reptiles did not reach the asymptote. These results suggest that the species richness in the NEIG is still underestimated, and more long-term studies are necessary for understanding the composition of the amphibian and reptile fauna species in the studied area.

\section{Conclusion}

The herpetofaunal diversity in the NEIG is similar to other restinga diversity studies along the Brazilian coast, and these results contribute to the herpetofaunal knowledge of the Brazilian Atlantic Rainforest diversity.

Although the NEIG represents a small remnant of Atlantic Rainforest, the records obtained in this study reinforce the need and importance of studies and conservation on the herpetofaunal composition in small remnants of this biome, which can still harbour undescribed and/or threatened species. Moreover, further detailed studies of the herpetofaunal composition are crucial for taking conservation measures and forming management plans suitable not only for Environmental Protection Areas, but also for many remaining areas of Atlantic Rainforest.

Acknowledgements - We are thankful to Luiz Freire and Rafael Bessa and to the Guarda Municipal de Iguaba Grande for their help in fieldwork. We also thank Paulo Passos, José Pombal Jr., Adriano Lima Silveira, Rodrigo Salles, Ana Carolina Calijorne, Délio Baêta, Clarissa Canedo and Marcos Bilate for their help with identification of the species. Thanks to Roberta Pinto and Bryan Jennings for valuable suggestions and review of the manuscript, and to Ronaldo Fernandes and Paulo Passos for help with the statistical analysis. We thank all members of the Setor de Herpetologia, Departamento de Vertebrados, Museu Nacional, Universidade Federal do Rio de Janeiro that in some form or other, contributed to this work.

\section{References}

ALMEIDA-GOMES, M., ALMEIDA-SANTOS, M., GOYANNESARAÚJO, P., BORGES-JÚNIOR, VNT., VRCIBRADIC, D., SIQUEIRA, CC., ARIANI, CV., DIAS, AS., SOUZA, VV., PINTO, RR., VAN SLUYS, M. and ROCHA, CFD., 2010. Anurofauna of an Atlantic Rainforest fragment and its surroundings in Northern Rio de Janeiro State, Brazil. Brazilian Journal of Biology, vol. 70, no. 3, p. 871-877. http://dx.doi.org/10.1590/ S1519-69842010000400018

ALMEIDA-GOMES, M., VRCIBRADIC, D., SIQUEIRA, CC., KIEFER, MC., KLAION, T., ALMEIDA-SANTOS, P., NASCIMENTO, D., ARIANI, CV., BORGES-JUNIOR, VNT., FREITAS-FILHO, RF., VAN SLUYS, M. and ROCHA, CFD., 2008. Herpetofauna of an Atlantic rainforest area (Morro São João) in Rio de Janeiro State, Brazil. Anais da Academia Brasileira de Ciências, vol. 80, no. 2, p. 291-300. http://dx.doi.org/10.1590/ S0001-37652008000200007

ARAÚJO, AFB., 1984. Padrões de divisão em uma comunidade de Lagartos de restinga. In LACERDA, LD.; ARAÚJO, DSD.; CERQUEIRA, R and TURCO, B. (Orgs.). Restingas, Origem, Estrutura e Processos. Niterói: Centro Editorial da Universidade Federal Fluminense. p. 327-342.

ARAUJO, CO., CONDEZ, TH., BOVO, RP., CENTENO, FC. and LUIZ, AM., 2010. Amphibians and reptiles of the Parque Estadual Turístico do Alto Ribeira (PETAR), SP: an Atlantic Forest remnant of Southeastern Brazil. Biota Neotropica, vol. 10, no. 4 , p. 256-274.

BERGALLO, HG., and ROCHA, CFD., 1993. Activity patterns and body temperatures of two simpatric lizards with different foraging tactics in southeastern Brazil. Amphibia-Reptilia, vol. 14, p. 312-315. http://dx.doi.org/10.1163/156853893X00525

BERTOLUCI, J., CANELAS, MAS., EISEMBERG, CC., PALMUTI, CFS. and MONTINGELLI, GG., 2009. Herpetofauna da Estação Ambiental de Peti, um fragmento de Mata Atlântica do estado de Minas Gerais, sudeste do Brasil. Biota Neotropica, vol. 9, no. 1, p. 147-155. http://dx.doi.org/10.1590/S1676-06032009000100017

BRITTO-PEREIRA, MC., CERQUEIRA, R., SILVA, HR. and CARAMASCHI, U., 1988. Anfíbios da restinga de Maricá, 
RJ: levantamento e observações preliminares sobre a atividade reprodutiva das espécies registradas. In Anais da VI Semana Regional de Ecologia, 1988. São Carlos. p. 295-306.

CAMPBELL, JA. and LAMAR, WW., 2004. The venomous reptiles of the western hemisphere. New York: Cornel University Press. 962 p.

CARVALHO, ALG., ARAÚJO, AFB. and SILVA, HR., 2007. Lagartos da Marambaia, um remanescente insular de restinga e floresta atlântica no estado do Rio de Janeiro. Biota Neotropica, vol. 7, no. 2, p. 220-226.

CARVALHO-E-SILVA, AMPT., SILVA, GR. and CARVALHO-ESILVA, SP., 2008. Anuros da Reserva Rio das Pedras, Mangaratiba, RJ, Brasil. Biota Neotropica, vol. 8, no. 1, p. 199-209. http:// dx.doi.org/10.1590/S1676-06032008000100021

CARVALHO-E-SILVA, SP., IZECKSOHN, E. and CARVALHO-ESILVA, AMPT., 2000. Diversidade e ecologia de anfíbios em restingas do sudeste brasileiro. In ESTEVES, FA. and LACERDA, LD. (Eds.). Ecologia de Restingas e Lagoas costeiras. Rio de Janeiro: NUPEM UFRJ. p. 89-97.

CECHIN, SZ. and MARTINS, M., 2000. Eficiência de armadilhas de queda (pitfall traps) em amostragens de anfíbios e répteis no Brasil. Revista Brasileira de Zoologia, vol. 17, no. 3, p. 729-740.

COLOMBO, P., KINDEL, A., VINCIPROVA, G. and KRAUSE, L., 2008. Composição e ameaças à conservação dos anfíbios anuros do Parque Estadual de Itapeva, Município de Torres, Rio Grande do Sul, Brasil. Biota Neotropica, vol. 8, no. 3, p. 228-240. http:// dx.doi.org/10.1590/S1676-06032008000300020

Companhia de Pesquisa de Recursos Minerais - CPRM, 2000. Mapa Geoambiental do Estado do Rio de Janeiro. Availabe from: $<\mathrm{ftp}: / / \mathrm{ftp}$. cprm.gov.br/pub/pdf/rj/geoambiental/geoambiental_ mpgeoambiental.pdf $>$. Acces in: 23 jul. 2009.

COSTA, HC., PANTOJA, DL., PONTES, JL. and FEIO, RN., 2010. Serpentes do Município de Viçosa, Mata Atlântica do Sudeste do Brasil. Biota Neotropica, vol. 10, no. 3, p. 353-377.

DIAS, EJR. and ROCHA, CFD. 2005. Os répteis nas restingas do Estado da Bahia: Pesquisa e ações para sua conservação. Rio de Janeiro: Instituto Biomas, $36 \mathrm{p}$.

DIAS, IR., VILAÇA, TRA., SILVA, JRS., BARBOSA, RS., and SOLÉ, M., 2010. Amphibia, Anura, Hylidae, Trachycephalus nigromaculatus Tschudi, 1838: Distribution extension. Check List, vol. 6, no. 3, p. 412-413.

DIXO, M. and VERDADE, VK., 2006. Herpetofauna de serrapilheira da Reserva Florestal de Morro Grande, Cotia (SP). Biota Neotropica, vol. 6, no. 2, p. 1-20. http://dx.doi.org/10.1590/ S1676-06032006000200009

DUELLMAN, WE., 1988. Patterns of species diversity in anuran amphibians in the American Tropics. Annals of the Missouri Botanical Garden, vol. 75, no. 1, p. 79-104. http://dx.doi. org/10.2307/2399467

-, 1989. Tropical herpetofaunal communities: patterns of community structure in Neotropical rainforests. In HARMELIN-VIVIEN, ML. and BOURLIÈRE, F. (Eds.). Vertebrates in Complex Tropical Systems. New York: Springer-Verlag. p. 61-88.

-, 1990. Herpetofaunas in Neotropical rainforests: Comparative composition, history, and resource use. In GENTRY, AH. (Ed.). Four Neotropical Rainforests. Connecticut: Yale University Press, p. 455-505.
FREITAS, MA. and SILVA, TFS. 2007. Guia ilustrado: a herpetofauna das caatingas e áreas de altitudes do Nordeste brasileiro. Pelotas: USEB. 388 p.

Fundação SOS Mata Atlântica, Instituto Nacional de Pesquisas Espaciais - INPE, 2001. Atlas dos remanescentes florestais da Mata Atlântica e ecossistemas associados no periodo 1995-2000. São Paulo. $156 \mathrm{p}$

GANDOLFI, SM. and ROCHA, CFD., 1998. Orientation of thermoregulating Tropidurus torquatus (Sauria: Tropiduriadae) on térmite mounds. Amphibia-Reptilia, vol. 19, p. 319-323.

HADDAD, CFB., TOLEDO, LF. and PRADO, CPA. 2008. Anfíbios da Mata Atlântica. São Paulo: Editora Neotropica. 242 p.

HEYER, WR., DONNELY, MA., ROY, WM., HAYEK, LC. and FOSTER, MS., 1994. Measuring and monitoring biological diversity. Washington and London: Smithsonian Institution Press. 364 p.

Instituto Brasileiro do Meio Ambiente e dos Recursos Naturais Renováveis - IBAMA. 2003. Lista das espécies da fauna brasileira ameaçadas de extinção. Available from: <http://www.ibama.gov. br/fauna/downloads/lista\%20spp.pdf>. Acess in: 13 ago. 2010.

Instituto de Pesquisas da Mata Atlântica - IPEMA, 2005. Conservação da Mata Atlântica no Espírito Santo: cobertura florestal e unidades de conservação. Vitória: IPEMA, Conservação Internacional. $142 \mathrm{p}$.

IZECKSOHN, E. and CARVALHO-E-SILVA, SP. 2001. Anfíbios do Município do Rio de Janeiro. Rio de Janeiro: Editora UFRJ. 148 p.

JUNCÁ, FA., 2006. Diversidade e uso de habitat por anfíbios anuros em duas localidades de Mata Atlântica, no norte do estado da Bahia. Biota Neotropica, vol. 6, no. 2, p. 1-17.

LAMEGO, AR., 1974. O Homem e a Restinga. 2nd ed. Rio de Janeiro: Editora Lidador. 305 p.

LUCAS, EM. and FORTES, VB., 2008. Frog diversity in the Floresta Nacional de Chapecó, Atlantic Forest of southern Brazil. Biota Neotropica, vol. 8, no. 3, p. 50-61.

MARQUES, OAV., PEREIRA, DN., BARBO FE., GERMANO, VJ. and SAWAYA, RJ., 2009. Os Répteis do Município de São Paulo: diversidade e ecologia da fauna pretérita e atual. Biota Neotropica, vol. 9, no. 2, p. 139-149.

MARTINS, AR., SILVEIRA, AL. and BRUNO, SF., 2010. New records of Typhlops brongersmianus (Serpentes, Typhlopidae) in southeastern Brazil. Herpetology Notes, vol. 3, p. 247-248.

MORAES, RA., SAWAYA, RJ. and BARRELA, W., 2007. Composição e diversidade de anfíbios anuros em dois ambientes de Mata Atlântica no Parque Estadual Carlos Botelho, São Paulo, sudeste do Brasil. Biota Neotropica, vol. 7, no. 2, p. 26-36.

MYERS, N., MITTERMEIER, RA., MITTERMEIER, CG., FONSECA, GAB. and KENT, J . 2000. Biodiversity hotspots for conservation priorities. Nature, vol. 403, no. 6771, p. 853-858. PMid:10706275. http://dx.doi.org/10.1038/35002501

NARVAES, P., BERTOLUCI, J. and RODRIGUES, MT., 2009. Composição, uso de hábitat e estações reprodutivas das espécies de anuros da floresta de restinga da Estação Ecológica Juréia-Itatins, sudeste do Brasil. Biota Neotropica, vol. 9, no. 2, p. 116-123.

PONTES, JAL. and ROCHA, CFD., 2008. Serpentes da Serra do Mendanha, Rio de Janeiro, RJ: ecologia e conservação. Rio de Janeiro: Technical Books. 147 p. 
PONTES, JAL., PONTES, RC. and ROCHA, CFD. 2009. The snake community of Serra do Mendanha, in Rio de Janeiro State, southeastern Brazil: composition, abundance, richness and diversity in areas with different conservation degrees. Brazilian Journal of Biology, vol. 69, no. 3, p. 795-804. http://dx.doi.org/10.1590/ S1519-69842009000400006

ROCHA, CFD. 2000. Biogeografia de répteis de restinga: distribuição, ocorrência e endemismos. In ESTEVES, FA. and LACERDA, LD. (Eds.). Ecologia de restingas e lagoas costeiras. Macé: NUPEM. 464 p.

ROCHA, CFD. and BERGALLO, HG., 1994. Tropidurus torquatus (Collared lizard) Diet. Herpetological Review, vol. 25, no. 2, p. 69.

,- 1997. Intercommunity variation in the distribution of abundance of dominant lizard species in restinga habitats. Ciência e Cultura, Journal of the Brazilian Association for the Advancement of Science, vol. 49, no. 4, p. 269-274.

ROCHA, CFD, BERGALLO, HG., POMBAL JUNIOR, JP, LENA, G., SLUYS, MV., FERNANDES, R. and CARAMASCHI, U. 2004a. Fauna de anfíbios, répteis e mamíferos do estado do Rio de Janeiro, Sudeste do Brasil. Publicações Avulsas do Museu Nacional, no. 104, p. 3-23.

ROCHA, CFD., HATANO, FH., VRCIBRADIC, D. and VAN SLUYS, M., 2008. Frog species richness, composition and 口-diversity in costal Brazilian restinga habitats. Brazilian Journal of Biology, vol. 68, no. 1, p. 101-107. http://dx.doi.org/10.1590/ S1519-69842008000100014

ROCHA, CFD. and VAN-SLUYS, M., 2006. New records of reptiles from Ilha Grande Island in Rio de Janeiro state, Brazil. Herpetological Review, vol. 37, no. 1, p. 112-114.

ROCHA, CFD., VAN SLUYS, M., VRCIBRADIC, D., HATANO, FH., GALDINO, CA., CUNHA-BARROS, M. and KIEFER, MCA., 2004b. Comunidade de Répteis da Restinga de Jurubatiba. In: ROCHA, CFD., ESTEVES, FA. and SCARNO, FR. (Eds.). Pesquisas Ecológicas de Longa Duração na Restinga de Jurubatiba: Ecologia, História Natural e Conservação. São Carlos: Holos Editora. p. 179-198.

RODRIGUES, MT., 2005. Conservação dos répteis brasileiros: os desafios para um país megadiverso. Megadiversidade, vol. 1, no. 1, p. $87-94$.

SALLES, ROL. and SILVA-SOARES, T., 2010. Répteis do município de Duque de Caxias, Baixada Fluminense, Rio de Janeiro, Sudeste do Brasil. Biotemas, vol. 23, no. 2, p. 135-144.

SALLES, ROL., WEBER, LN. and SILVA-SOARES, T., 2010. Reptiles, Squamata, Parque Natural Municipal da Taquara, municipality of Duque de Caxias, state of Rio de Janeiro, Southeastern Brazill. Check List, vol. 6, no. 2, p. 280-286.

SANTANA, GG.,VIEIRA, WLS., PEREIRA-FILHO, A., DELFIM, FR., LIMA, YCC. and VIEIRA, KS., 2008. Herpetofauna em um fragmento de Floresta Atlântica no Estado da Paraíba, Região Nordeste do Brasil. Revista Biotemas, vol. 21, no. 1, p. 75-84.

SERAFIM, H., CICCHI, PJP., IENNE, S. and JIM, J., 2008. Anurofauna de remanescentes de floresta Atlântica do município de São José do Barreiro, estado de São Paulo, Brasil. Biota Neotropica, vol. 8, no. 2, p. 68-78.

SILVA, HR., CARVALHO, ALG. and BITTENCOURT-SILVA, GB. 2008. Frogs of Marambaia: a naturally isolated Restinga and Atlantic Forest remnant of southeastern Brazil. Biota Neotropica, vol. 8, no. 4, p. 166-174.

SILVANO, DL. and SEGALLA, MV., 2005. Conservação de anfíbios no Brasil. Megadiversidade, vol. 1, no. 1, p. 79-86.

SILVEIRA-PRIMO, PB. and BIZERRIL, CRSF. 2000. Perfil Ambiental do Maior Ecossistema Lagunar Hipersalino do Mundo. Rio de Janeiro: Semads. $160 \mathrm{p}$.

SOUSA, BM., NASCIMENTO, AER., GOMIDES, SC., VARELA RIOS, CH., HUDSON, AH. and NOVELLI, IA., 2010. Répteis em fragmentos de Cerrado e Mata Atlântica do Campo das Vertentes, Estado de Minas Gerais, Sudeste do Brasil. Biota Neotropica, vol. 10 , no. 2 , p. $129-138$

TABARELLI, M., SILVA, JMC. and GASCON, C., 2004. Forest fragmentation, synergisms and the impoverishment of neotropical forests. Biodiversity and Conservation, vol. 13, no. 13, p. 14191425. http://dx.doi.org/10.1023/B:BIOC.0000019398.36045.1b

TEIXEIRA-FILHO, P., ROCHA, CFD. and RIBAS, S., 2003. Relative feeding specialization may depress ontogenetic, seasonal and sexual variations in diet: the endemic lizard Cnemidophorus littoralis. Brazilian Journal of Biology, vol. 63, no. 2, p. 321-328. http://dx.doi.org/10.1590/S1519-69842003000200017

VANZOLINI, PE., RAMOS-COSTA, AMM. and VITT, LJ., 1980. Répteis das Caatingas. Rio de Janeiro: Academia Brasileira de Ciências. $161 \mathrm{p}$.

VECCHI, MB and ALVES, MAS., 2008. New records of the Restinga antwren Formicivora littoralis (Aves, Thamnophilidae) in the state of Rio de Janeiro, Brazil: inland extended range and threats. Brazilian Journal of Biology, vol. 68, no. 2, p.391-395. http://dx.doi.org/10.1590/S1519-69842008000200022

VILELA, VMFN., BRASSALOTI, RA. and BERTOLUCI, J., 2011. Anurofauna da floresta de restinga do Parque Estadual da Ilha do Cardoso, Sudeste do Brasil: composição de espécies e uso de sítios reprodutivos. Biota Neotropica, vol. 11, no. 1, p. 1-11.

VITT, LJ., 1987. Communities. In SEIGEL, RA., COLLINS, JT. and NOVAK, SS. (Eds.). Snakes: Ecology and Evolutionary Biology. New York: McGraw-Hill Publishing. 529 p.

WACHLEVSKI, M. and ROCHA, CFD. 2010. Amphibia, Anura, restinga of Baixada do Maciambu, municipality of Palhoça, state of Santa Catarina, southern Brazil. Check List, vol. 6, no. 4, p. $602-604$. 